\title{
Experimental Studies on Toxicity of Tin in Canned Orange Juice
}

(Received September 26, 1972)

\author{
Yoshihito OMORI*1, Akira TAKANAKA*1, Satoru TANAKA*1, Yoshio Ikeda*2 \\ and \\ Tsuyoshi FURUYA*2 \\ (*1Dept. of Pharamacology and *2Dept. of Toxicology, National Institute of Hygienic \\ Sciences: 18-1, Kamiyoga 1-chome, Setagaya-ku Tokyo)
}

\begin{abstract}
Vomiting and diarrhoea occurred in cats given a $10 \mathrm{ml}$ per kilozram dose of canned orange juice sample containing high concentration of tin ( $452 \mathrm{ppm})$, which also developed intoxications in man. Increase of tin concentration by condensation of the sample resulted in an acceleration of onset of toxic manifestations, however, adjustment of $\mathrm{pH}$ value to neutral range appeared to have little effect on the development of gastro-intestinal disorders. Presence of tin as complex with citrate in the sample was suspected and the tin complex prepared from stannic chloride and sodium citrate was given to cats as aqueous solution at various doses. Administration of the complex with doses above $9 \mathrm{mg}$ tin per kilogram developed toxic effects in every animal tested. Toxic effects of the juice sample disappeared after removal of tin by hydrogen sulfide treatment, but symptoms appeared again following the addition of as much tin to the treated sample as pretreatment level. Thus high concentration of tin in orange juice was suspected to be a cause of intoxication.
\end{abstract}

Metallic tin when taken by mouth is practically harmless, though a very large dose of salt will produce toxic symptoms (Unger and Boedlander). ${ }^{1)}$

Tin salts are toxic when parenterally administered causing spasms, fatal paralysis, gastro-intestinal disturbances with bleeding and also produce pathological changes in liver, spleen and other organs (Seifter and Rambousek).2)

Salant and Smith $^{3)}$ observed vomiting and diarrhoea in cats and dogs given $10 \mathrm{mg}$ and $25 \mathrm{mg}$ tin tartarate, respectively.

According to Pendergrass and Pryde ${ }^{4)}$ little absorption of tin will occur from the alimentary tract at least in the form present in canned food, and Buchanan and Schryver ${ }^{5}$ also assumed that there is little likelihood of chronic tin intoxication from canned food.

Luff and Metcalfe ${ }^{\text {() }}$ reported a case of tin intoxication after intake of canned cherries containing high level of $730 \mathrm{ppm}$ tin and four people developed severe nausea, vomiting, diarrhoea and collapse. An outbreak of acute severe gastrointestinal symptoms was reported on 31 people in the United States after drinking fruit punch delivered in re-timed milk container which con- tained 2000 ppm tin. ${ }^{7)}$

Since 1962, several cases of intoxication with canned orange juice have been observed in this country. Main symptoms are nausea, vomiting, diarrhoea, fever and headache, however, most of the patients recovered within a day or two without leaving any apparent disorders ${ }^{8)}$.

The inside surface of the can of toxic juice was covered with black thin rusty layer, but could not distinguish any odorous taste or smell from nontoxic control samples.

Physico-chemical examinations revealed that the toxic sample contained high concentration of tin compared with control, $425 \mathrm{ppm}$ and $84 \mathrm{ppm}$, respectively.

In microbiological examinations contamination with bacteria or fungi was proved to be negative.

Thus, it was suspected that the sample containing tin in high concentration may be a cause of acute intoxication and present experiments were undertaken.

\section{Experimentals}

Animals In preliminary observations, administration of $0.5 \mathrm{ml}$ and $5 \mathrm{ml}$ of the toxic samples to 
mice and rats developed no apparent abnormal signs. Adult cats weighing 1.7 to $2.9 \mathrm{~kg}$ were used throughout the experiment.

Orange juice samples Six canned samples were used. One toxic sample contained $452 \mathrm{ppm}$ tin and the other five collected from the market containing 84, 183,185, 325 and $337 \mathrm{ppm}$ of tin, respectively.

Complex of tin with citric acid This tin complex was prepared by the method of Seifter and Rambousek $^{2)}$ from stannic chloride and sodium citrate solution. The crystal obtained from evaporation of aqueous layer containing 29.5 percent tin was used. Oral $\mathrm{LD}_{50}$ of this sample in male mice was $2.7 \mathrm{~g} / \mathrm{kg}$.

Method of administration All test samples were given orally by gastric tube at a dose level of $10 \mathrm{ml}$ per $\mathrm{kg}$ body weight. Tin complex was dissolved either in orange juice or in water at various concentrations before administration.

Animals were fasted overnight before use and observed at least 6 hours after administration of the samples. Some of the experimental animals were sacrificed between 6 and 24 hours or 7 days after the administration and occurrence of toxic symptoms and changes in gastro-intestinal tract, liver, kidney and other organs were observed with unaided eye.

\section{Results}

1) Effect of oral administration of juice samples to cats

Twenty-four cats were divided into 6 groups and distilled water was administered to one group. All animals decreased spontaneous movement for about an hour after administration. Animals received distilled water and juice samples containing less than $337 \mathrm{ppm}$ of tin recovered within about 3 hours. But, six cats administered suspected sample developed some toxic symptoms (Table 1). Vomiting was observed in some animals of D-3518 (452 ppm tin) group between $90 \mathrm{~min}$. and 3 hours after the sample administration and also developed profused salivation for about 3 hours. Each animal vomited once or four times during the early stage of experiment and two of them excreted waterly stool after 5 to 6 hours. All visible symptoms disappeared within 8 hours and animals improved their appetite within 24 hours and body weight gain was observed thereafter. Brain, heart, liver, kidney and gastrointestinal tract were examined after 48

Table 1. Effect of Oral Administration of Canned Orange Juice on Cats Asterisks in the table indicate number of vomiting.

\begin{tabular}{c|c|c|c|c|c|c}
\multicolumn{2}{c|}{ Sample } & \multicolumn{2}{c|}{ Dose } & \multicolumn{3}{c}{ Symptoms } \\
\hline No. & mg Sn/1 & $\mathrm{m} 1 / \mathrm{kg}$ & $\mathrm{mg} \mathrm{Sn} / \mathrm{kg}$ & Vomiting & Diarrhea & Duration \\
\hline control & (distilled water) & 10 & & $0 / 4$ & & \\
A-3612 & 84 & 10 & 0.84 & $0 / 4$ & & \\
C-3223 & 183 & 10 & 1.83 & $0 / 2$ & & \\
C-3519 & 325 & 10 & 3.25 & $0 / 4$ & & \\
C-3515 & 337 & 10 & 3.37 & $0 / 4$ & & \\
D-3518 & 452 & 10 & 4.52 & $5 / 6$ & $2 / 6$ & $90-180$ min 6*
\end{tabular}

hours. At autopsy, any gross pathological finding which is assumed to be due to the administration of the samples was not noticed.

2) Effect of condensation of juice on the development of toxic symptoms in cats

Fourteen cats were used in this experiment. Sample A-3612 and D-3518 were lyophilized and then water was added to bring the concentration of tin in each sample to four times of original values, namely $336 \mathrm{ppm}$ and $1808 \mathrm{ppm}$, respec- tively. Administration of condensed A-3612 juice to 2 cats did not show any toxic change as in 4 cats received the original preparation. In two cats administered condensed sample D-3518 vomiting occurred at 40 and 60 minutes, although the same symptom developed not earlier than 90 min when the sample was given without condensation (Table 2). Thus, presence of tin in high concentration in the juice seemed to accelerate the onset of vomiting. 
3) Effect of $\mathrm{pH}$ adjustment of juice on the development of toxic sympoms in cats

$\mathrm{pH}$ values of sample D-3518 and C-3225 measured with glass electrode meter were 3.35 and 3.10 . These values were adjusted with sodium hydroxide solution to 6.95 and 7.00 , respectively. To six cats, of 4 groups, samples were given before and after adjustment of $\mathrm{pH}$. No unusual finding was observed in two groups of cats administered C-3225 samples (Table 2). At autopsy performed six hours after gavage no visible gross effect was noticed in every animal tested. Thus, the adjust- ment of $\mathrm{pH}$ values of juice to neutral range was] not assumed to affect the toxic effect remarkably.

4) Effect of oral administration of aqueous solution of tin complex to cats

Tin complex prepared with stannic chloride and sodium citrate containing $29.5 \%$ tin was dissolved in distilled water at various concentration and given to cats at a dose of $10 \mathrm{ml}$ per kilogram. Stannic chloride solution was also used. Each one of four cats vomited once in groups administered 7.6 and $15.2 \mathrm{mg} / \mathrm{kg}$ sample, and all animals received tin complex and stannic chloride more

Tabel 2. Effect of Condensation and pH Adjustment on the Toxicity of Orange Juice in Cats Asterisks in the table indicate number of vomiting.

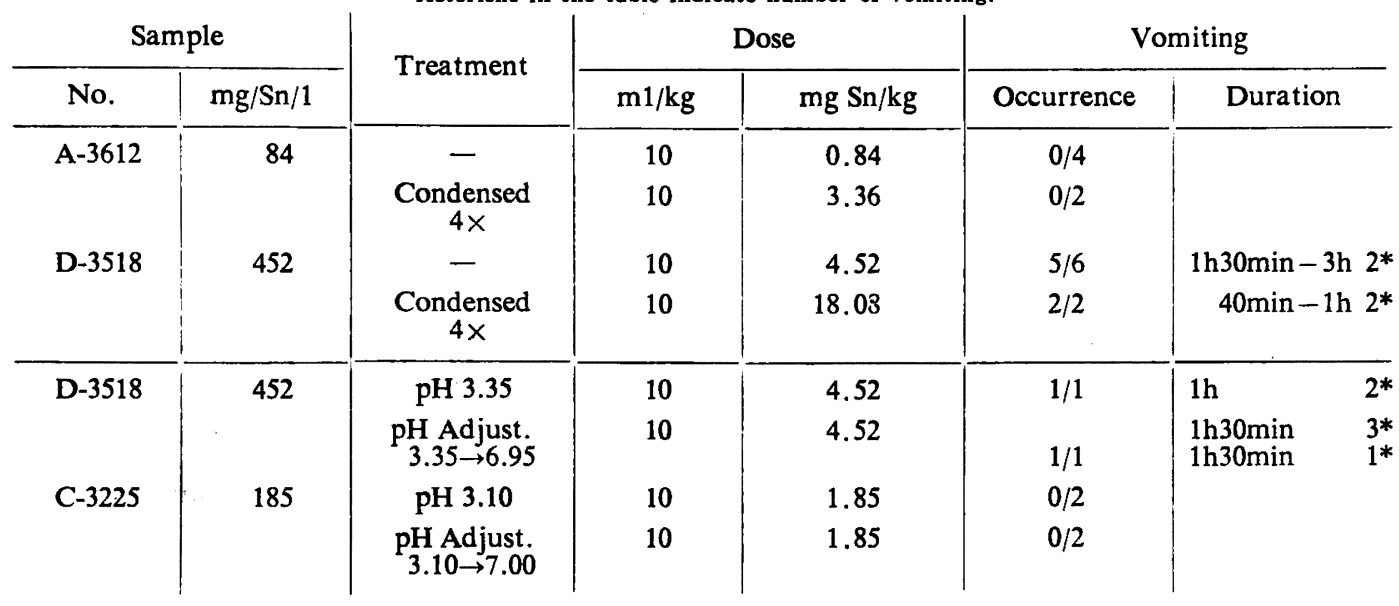

Table 3. Toxic Effect of Tin Complex Solution on Cats (Sn: $29.5 \%$ )

Asterisks in the table indicate number of vomiting.

\begin{tabular}{|c|c|c|c|c|c|}
\hline Sample & \multicolumn{2}{|c|}{ Dose } & \multicolumn{3}{|c|}{ Vomiting } \\
\hline $\mathrm{mg} / \mathrm{kg}$ & $\mathrm{m} 1 / \mathrm{kg}$ & $\mathrm{mg} \mathrm{Sn} / \mathrm{kg}$ & Occurrence & Duration & \\
\hline Distilled water & 10 & & $0 / 7$ & & \\
\hline 2.9 & 10 & 0.8 & $0 / 2$ & & \\
\hline 7.6 & 10 & 2.3 & $1 / 4$ & $1 \mathrm{~h} 25 \mathrm{~min}$ & $1^{*}$ \\
\hline 15.2 & 10 & 4.5 & $1 / 4$ & $1 \mathrm{~h} 30 \mathrm{~min}$ & $1^{*}$ \\
\hline 21.5 & 10 & 6.3 & $0 / 2$ & & \\
\hline 30.4 & 10 & 9.0 & $2 / 2$ & $\begin{array}{l}1 \mathrm{~h} 30 \mathrm{~min} \\
1 \mathrm{~h} 15 \mathrm{~min}, 1 \mathrm{~h} 40 \mathrm{~min}: \frac{1}{2}\end{array}$ & $2^{*}$ \\
\hline 76 & 10 & 22.5 & $2 / 2$ & $\begin{array}{r}25 \mathrm{~min}-2 \mathrm{~h} 26 \mathrm{~min} \\
1 \mathrm{~h} 05 \mathrm{~min}, 1 \mathrm{~h} 58 \mathrm{~min}\end{array}$ & $\begin{array}{l}6^{*} \\
2^{*}\end{array}$ \\
\hline 152 & 10 & 45.0 & $1 / 1$ & $30 \mathrm{~min}-1 \mathrm{~h} 50 \mathrm{~min} \quad 3$ & $3 *$ \\
\hline 304 & 10 & 90.0 & $2 / 2$ & $\begin{array}{l}20 \mathrm{~min}, \\
60 \mathrm{~min}\end{array}$ & $\begin{array}{l}2^{*} \\
1^{*}\end{array}$ \\
\hline 760 & 10 & 225.0 & $2 / 2$ & $\begin{array}{l}30 \mathrm{~min}-2 \mathrm{~h} 40 \mathrm{~min} \\
40 \mathrm{~min}-1 \mathrm{~h} 30 \mathrm{~min}\end{array}$ & $5^{*}$ \\
\hline Stannic chloride & 10 & 9.0 & $2 / 2$ & $\begin{array}{r}45 \min -2 \mathrm{~h} 32 \min \\
1 \mathrm{~h} 40 \mathrm{~min}-2 \mathrm{~h} 25 \mathrm{~min} \\
5\end{array}$ & $\begin{array}{l}5 * \\
5 *\end{array}$ \\
\hline
\end{tabular}


than $9 \mathrm{mg} / \mathrm{kg}$ as tin developed severe salivation and vomiting (Table 3 ).

5) Effect of removal and addition of tin complex on the toxicity of orange juice.

Tin complex was added to C-3225 orange juice sample and large amount of $13.6 \mathrm{mg} \mathrm{tin} / 10 \mathrm{ml} / \mathrm{kg}$ was administered to two cats. Both animals developed severe toxic symptoms (Table 4). This tin-added sample was treated with hydrogen sulfide for three hours, filtered, aerated to remove the gas and then eluted through activated charcoalcelite $(1: 1)$ column (Figure 1). Administration of the same volume of this tin-removed solution to cats did not show any toxic sign. To the tinremoved solution, tin complex was added again to bring the tin content as much as $1360 \mathrm{ppm}$. This preparation was administered to two cats and similar toxic symptoms as observed in the initial

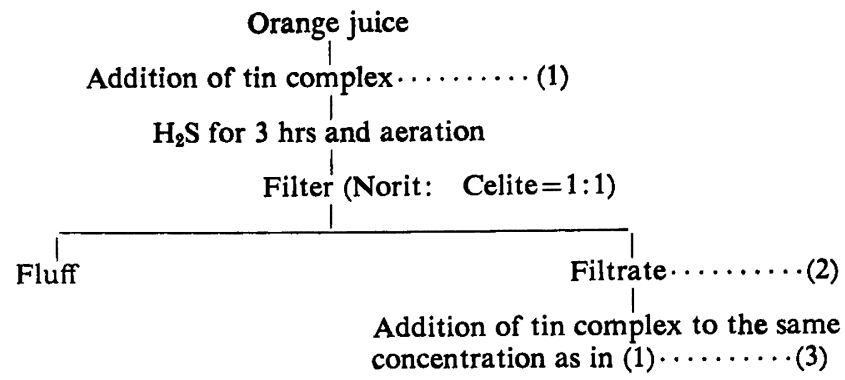

Polarography and animal experiments were carried out with (1), (2) and (3) samples.

Fig. 1. Treatment of orange juice for addition and removal of tin

Table 4. Effect of Addition and Removal of Tin Complex on the Toxicity of Orange Juice in Cats Numerals in parentheses indicate re-examined values of tin concentration, and asterisks show numbers of vomiting.

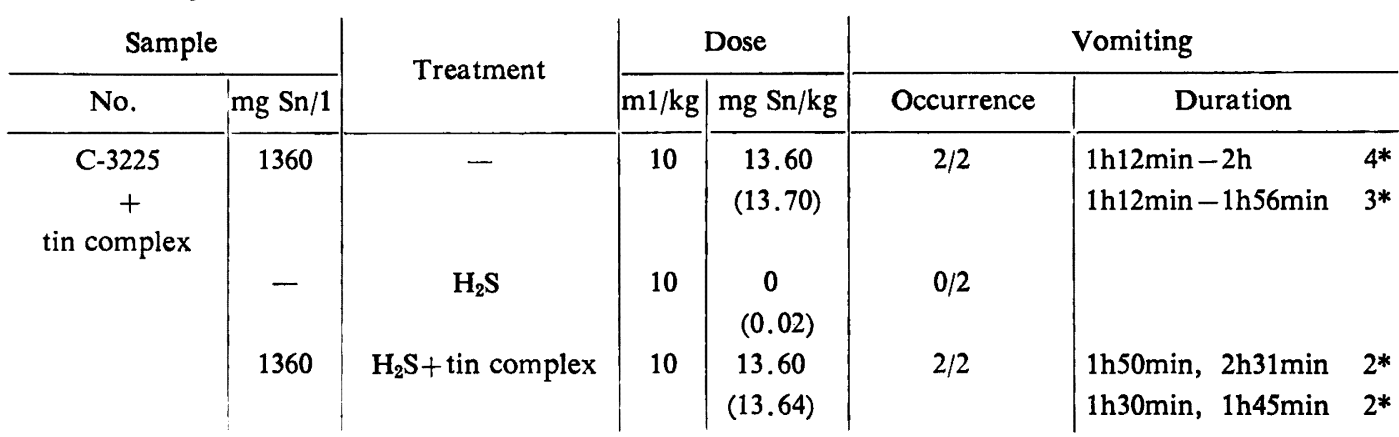

tin-added sample group were developed (Table 4).

6) Effect of administration of extracts of orange juice to cats

Two samples of orange juice were extracted and fractionated as usual according to the method of Staudinger (Fig. 2). The sample was extracted with ether and then with water. Tin was found in ether-insoluble phase. Water-soluble fractions from ether-soluble and insoluble fractions were administered to cats. As shown in Table 5, toxic symptom was not observed in cats received ethersoluble and water-soluble fraction which did not cotain tin. Two samples obtained from etherinsoluble and water-soluble fractions developed vomiting in cats. Fraction SF III from control sample contained $290 \mathrm{ppm}$ of tin and toxic symptom developed in one cat after $150 \mathrm{~min}$. But, in another group of cats, which received sample containing $1060 \mathrm{ppm}$ of tin, the toxic symptoms were observed within $35 \mathrm{~min}$. after administration and continued as long as $2 \mathrm{hrs}$. Salivation and prostration in this group was more severe than observed in control group.

\section{Discussion}

The purpose of present study was to assess the cause of the toxic effect of orange juice which contained fairly high level of tin. 


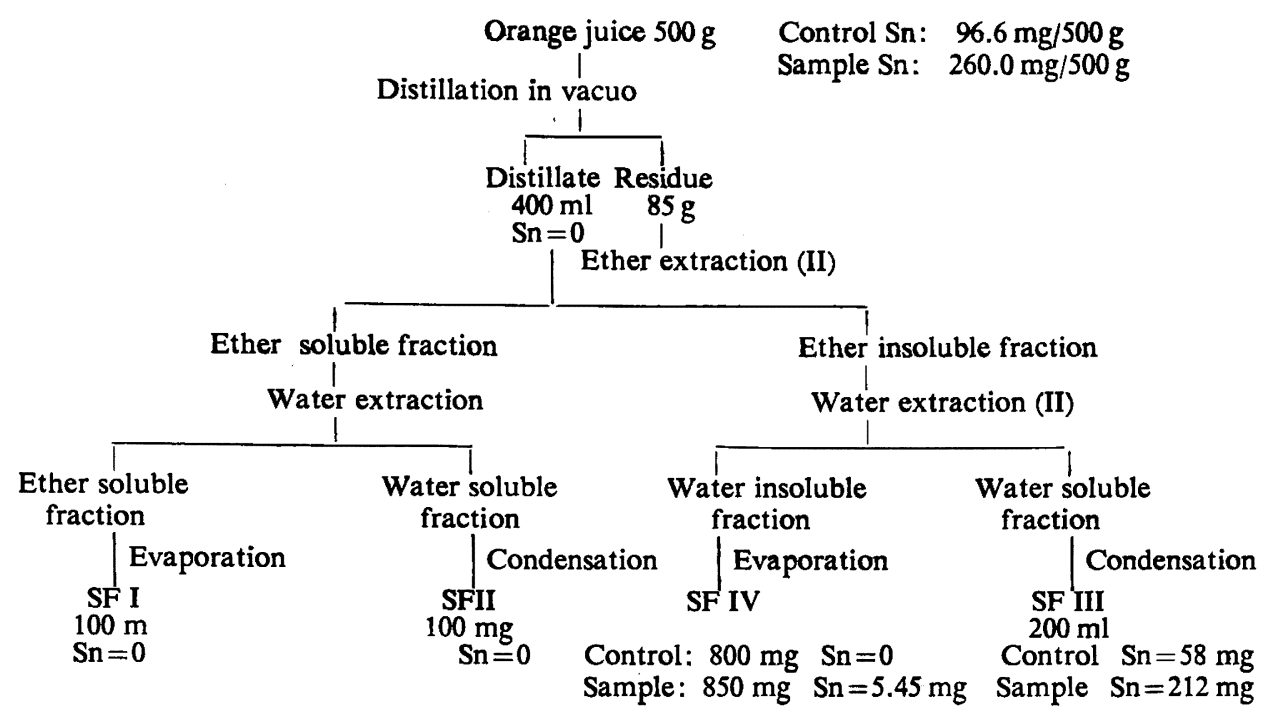

Fig. 2. Fractionation of orange juice.

Table 5. Effect of Fractionation of Orange Juice on the Toxity in Cats Asterisks in the table indicate numbers of vomiting.

\begin{tabular}{|c|c|c|c|c|c|c|}
\hline \multicolumn{2}{|c|}{ Fraction } & \multicolumn{2}{|c|}{ Dose } & \multicolumn{3}{|c|}{ Vomiting } \\
\hline No. & $\mathrm{mg} \mathrm{Sn} / 1$ & $\mathrm{~m} 1 / \mathrm{kg}$ & $\mathrm{mg} \mathrm{Sn} / \mathrm{kg}$ & Occurrence & Duration & \\
\hline \multirow{2}{*}{ SF II } & 0, Control & 10 & - & $0 / 2$ & - & \\
\hline & 0, Sample & 10 & - & $0 / 2$ & - & \\
\hline \multirow{2}{*}{ SF III } & 290, Control & 10 & 2.9 & $1 / 2$ & $150 \mathrm{~min}$ & $2^{*}$ \\
\hline & 1060, Sample & 10 & 10.6 & $2 / 2$ & $35 \mathrm{~min}-120 \mathrm{~min}$ & $6 *$ \\
\hline
\end{tabular}

On the findings obtained in preliminary experiment, adult cats were used in the present study, although only mixed-bred and mixed sexes were available. Experimental animals were used only once because animals were assumed to become tolerant to the sample's toxic effects after repeated administration in the preliminary observations.

Administration of $10 \mathrm{ml}$ per kilogram of orange juice which contained $452 \mathrm{ppm}$ of tin developed vomiting in about $80 \%$ of cats examined. Diarrhoea was not observed in most of the animals used.

The $\mathrm{pH}$ values of canned orange juice were relatively low, but adjustment of the values to around neutral range was assumed not to affect the development of toxicity of the samples.

Chemical nature of tin complex used in this study is not yet known as well as in what form tin is present in water solution or in orange juice. Horio ${ }^{9)}$ is working to $\&$ cidate these problems.

When tin complex was administered as an aqueous solution vomiting was not always observed with the increase of doses between 0.8 and 6.3 $\mathrm{mg}$ tin $/ \mathrm{kg}$ level, but the symptom was observed in every cat that received the compound more than $9 \mathrm{mg}$ tin $/ \mathrm{kg}$. Also, severity of symptom did not always increase parallel with the dose.

Increase of tin content in the juice by condensation or by addition of tin complex seemed to increase the toxicity of orange juice, though increase in density and sugar content by condensation may change the development of vomiting. After extraction of tin containing orange juice with ether and then with water, most of tin was found in ether-insoluble and water-soluble fraction (SF III). Administration of this SF III fraction to 
cats, $2.9 \mathrm{mg}$ tin $/ \mathrm{kg}$ developed vomiting in one cat of two, but the toxic symptom became more severe with $10.6 \mathrm{mg}$ tin $/ \mathrm{kg}$ group.

These finding will show that high concentration of tin in orange juice or water solution may induce vomiting.

Cheftel ${ }^{10)}$ reported a review on the major incidences of poisonings noticed between 1907 and 1967 which may be attributable to tin toxicity and stated that it appears indisputable that such large doses as the order of several hundred milligrams for an adult have caused a certain number of cases of poisoning, though the limit of $250 \mathrm{mg}$ tin/ $\mathrm{kg}$ food contains a wide margin of safety.

Benoy and coworkers ${ }^{11)}$ studied the effects of tin-containing fruits juice after oral administration to pigeons, rats, cats, dogs and human volunteers. In these experiments only cat and man showed gastro-intestinal disturbances. One cat out of 22 vomited after an $10 \mathrm{ml} / \mathrm{kg}$ dose of orange juice containing $540 \mathrm{ppm}$ of tin derived from container, and with juice containing $1370 \mathrm{ppm}$ of tin $20-30 \%$ of the cats vomited. Fruits juice containing $2000 \mathrm{ppm}$ of tin caused vomiting in up to $40 \%$ of cats examined. The higher incidence of vomiting in cats was observed in $5 \mathrm{ml} / \mathrm{kg}$ group than $10 \mathrm{ml} / \mathrm{kg}$ of $2000 \mathrm{ppm}$ sample and high tin concentration of the juice was assumed to be more important than the total amount ingested as was suggested in the present experiments. On these findings Benoy and coworkers stated that the occurrences of vomiting in individual cats were erratic.

There are some discrepancies among results on the amount and concentration of tin required to produce toxic effect. But, it may be reasonable to assume that high content of tin may cause local irritation after intake of the juice and develop gastro-intestinal disorders.

\section{Acknowledgment}

The authors wish to express their thanks to Dr. T. Okada and Mr. T. Tatsuno of the Department of Food Chemistry of our institute for the preparation of tin-complex and tin analysis by polarography.

\section{Bibliography}

1) Unger, E., Boedlander, G.: Z. Hyg. Infekt.-kr. 2, 241 (1887).

2) Seifter, J., Rambousek, E.S.: J. Lab. Clin. Med. 28, 1344 (1943).

3) Salant, W., Smith, C.S.: J. Pharmacol. 5, 517 (1914).

4) Pendergrass, J., Pryde, A.W.: J. Industr. Hyg. Toxicol., 30, 119 (1948).

5) Buchanan, G.S., Schryver, S.B.: Brit. Food J., 11, 101 (1909).

6) Luff, A.P., Metcalfe, J.H.: Brit. Med. J., 1, $833(1890)$.

7) Warburton, S., Ulder, W., Ewert, R. M., Haynes, W.S.: Publ. Hlth. Rep. Wash. 77, 798 (1962).

8) Omori, Y., Takanaka, A., Ikeda, Y., Furuya, T.: Folia Pharmacol. Jap. 61, 77 (1955).

9) Horio, K.: Personal communication.

10) Cheftel, H.: Fourth Meeting of the Codex Committee on Food Additives (Codex Alimentarius). (1967).

11) Benoy, C.G., Hooper, P.A., Schneider, R.: Fd. Cosmet. Toxicol. 9, 645 (1971). 